Volume 4 | Issue 1

2016

\title{
What Do We Regret and Why?
}

Richard Delgado

University of Alabama School of Law, rdelgado@law.ua.edu

Jean Stefancic

University of Alabama, jstefancic@law.ua.edu

Follow this and additional works at: https://scholarship.law.tamu.edu/lawreview

Part of the Law Commons

\section{Recommended Citation}

Richard Delgado \& Jean Stefancic, What Do We Regret and Why?, 4 Tex. A\&M L. Rev. 123 (2016)

(reviewing Steven W. Bender, Mea Culpa: Lessons on Law and Regret from U.S. History (2015)).

This Review is brought to you for free and open access by Texas A\&M Law Scholarship. It has been accepted for inclusion in Texas A\&M Law Review by an authorized editor of Texas A\&M Law Scholarship. For more information, please contact aretteen@law.tamu.edu. 


\title{
REVIEW
}

\section{WHAT DO WE REGRET AND WHY?}

\author{
Richard Delgado* \\ Jean Stefancic**
}

Mea Culpa: Lessons on Law and Regret from U.S. History. By Steven W. Bender. New York and London: New York University Press. 2015. 188 pp. + notes. Cloth, $\$ 35.00$.

\section{TABle of CONTENTS}

I. Introduction .................................. 123

II. Why We Go Astray ....................... 128

A. Dehumanization .......................... 128

B. Law as Safeguard ......................... 130

1. In Law, Reversal Is Rare and Structurally Isolated ................................. 131

2. An Adversary System Based on Argumentative Skill.................................. 133

3. Stare Decisis ("My Hands Are Tied") ........ 133

4. Clarence Darrow's Predicament: Brilliant Retorts and the Empathic Fallacy ........... 134

C. Law's Limits and the Reconstructive Paradox....... 135

III. Conclusion .................................... 136

\section{INTRODUCTION}

Our fast-paced world calls on us to make many decisions quickly and with little confidence they will hold up to future judgment. Will hydraulic fracturing ("fracking") poison the environment, or will it liberate us from economic dependence on oil-rich oligarchs in the volatile Middle East? ${ }^{1}$ Should we make amends to African-Americans for slavery and Jim Crow laws, as Congress recently did for lynching ${ }^{2}$

* John J. Sparkman Chair of Law, University of Alabama School of Law.

** Professor and Clement Research Affiliate, University of Alabama School of Law. Thanks to Jessica Lesnau and Miriam Garza for research and editorial assistance and to the Texas Institute for Advanced Study, Texas A\&M University School of Law, and Centrum Center for the Arts for scholarly support.

1. See Coral Davenport, New Federal Rules Are Set for Fracking, N.Y. Trmes (Mar. 20, 2015), http://www.nytimes.com/2015/03/21/us/politics/obama-administrationunveils-federal-fracking-regulations.html (offering an example of the controversy over fracking's benefits and risks).

2. Avis Thomas-Lester, A Senate Apology for History on Lynching, WASH. Post (June 14, 2005), http://www.washingtonpost.com/wp-dyn/content/article/2005/06/13/ AR2005061301720.html [https://perma.cc/JPW2-DGZY].

DOI: https://doi.org/10.37419/LR.V4.I1.4 
and the internment of Japanese-Americans during World War $\mathrm{II}^{3}$ and as a few private institutions have done for profiting from the slave trade $?^{4}$ Or would doing so merely reward people who did not personally suffer the injury while punishing those who had nothing to do with it?

Much of the Southwest was once part of Mexico and fell under American control as a result of a war of territorial aggression. ${ }^{5}$ Should we, therefore, modify our harsh treatment of immigrants from that region, many of whom are merely migrating to land that once belonged to their ancestors?

Across the nation, the crime rate is down, ${ }^{6}$ but our prisons are still dangerously overcrowded. ${ }^{7}$ Should we, therefore, decriminalize minor offenses such as possession of small amounts of marijuana? ${ }^{8}$ What does the history of Prohibition teach? ${ }^{9}$

What are we currently doing, perhaps because we are ignoring the lessons of history, that we might one day regret? Indeed, what are those lessons and how do we know which ones are valid? Today we wonder how the Supreme Court could have handed down decisions like Dred Scott v. Sandford ${ }^{10}$ Plessy v. Ferguson, ${ }^{11}$ Buck v. Bell, ${ }^{12}$ and

3. Civil Liberties Act of 1988, Pub. L. No. 100-383, 102 Stat. 903, 903-04 (codified as amended at 50 U.S.C. app. $\$ \$ 1989-1989$ b (2012)).

4. Brittany M. Llewellyn \& Alexandra Perloff-Giles, Slavery Ties Left Unexplored, Harv. CRIMson (Apr. 25, 2008), http:/www.thecrimson.com/article/2008/4/ 25/slavery-ties-left-unexplored-with-initiatives/ [https://perma.cc/XMJ6-APER] (noting that some institutions, including universities, benefitted from slavery and explaining steps they have taken to make amends).

5. Amy S. Greenberg, A Wicked War: Polk, Clay, lincoln, and the 1846 U.S. Invasion of Mexico (Vintage Books 2013) (2012) (documenting that war's pretextual nature and opportunistic aims).

6. Charles C. W. Cooke, Careful with the Panic: Violent Crime and Gun Crime Are Both Dropping, Nat'l Rev.: The Corner (Nov. 30, 2015, 1:04 PM), http:// www.nationalreview.com/corner/427758/careful-panic-violent-crime-and-gun-crimeare-both-dropping-charles-c-w-cooke [https://perma.cc/W3AJ-VRXB?type=image] (noting that violent crime has been declining).

7. Jonathan Simon, Mass Incarceration on Trial (2014) (noting that the judiciary is beginning to press states to reduce reliance on incarceration as a means of social control).

8. See Richard Delgado \& Jean Stefancic, Critical Perspectives on Police, Policing, and Mass Incarceration, 104 GEO. L.J. 1531 (2016) (suggesting this approach).

9. See Daniel Okrent, Last Call: The Rise and Fall of Prohibition 373 (1st Scribner hardcover ed. 2010) (judging the policy largely a failure).

10. Dred Scott v. Sandford, 60 U.S. 393 (1857) (deeming African-Americans incapable of holding U.S. citizenship). equal).

11. Plessy v. Ferguson, 163 U.S. 537 (1896) (upholding the regime of separate but

12. Buck v. Bell, 274 U.S. 200 (1927) (upholding Virginia's eugenic sterilization measure); see also Adam Cohen, Imbeciles: The Supreme Court, American Eugenics, AND the Sterilization of CARRIE Buck (2016) (discussing how eugenics advocates influenced eight Supreme Court justices to legitimize eugenic sterilization). 
Bowers v. Hardwick. ${ }^{13}$ Are we doing anything now that may cause our own descendants to ask what on earth we were thinking? ${ }^{14}$

Mea Culpa: Lessons on Law and Regret from U.S. History by Steven W. Bender wrestles with questions like these. A welcome respite from the flood of celebratory, upbeat writing about American legal history, ${ }^{1.5}$ it does not sidestep hard questions or dismiss them as presentist,$^{16}$ much less go easy on contemporary leaders who continue evil practices merely because they are commonplace. ${ }^{17}$

Bender's main thesis is that most of what we now regard as historic injustices ${ }^{18}$ resulted from dehumanization-the failure to consider the full humanity of other people. ${ }^{19} \mathrm{He}$ also issues a warning for today's policymakers: The circle of human concern is constantly expanding, so many current practices are likely to appear inexcusable with the passage of time. ${ }^{20}$ Bender traces past mistreatment of Native Americans, African-Americans, and other groups to our construction of them as inhuman and thus entitled to little consideration. ${ }^{21} \mathrm{He}$ then applies this lesson to modern treatment of immigrants, ${ }^{22}$ farm workers, ${ }^{23}$ the poor and homeless (thanks to our system of corporate capitalism) ${ }^{24}$ LGBT people, ${ }^{25}$ prisoners on death row, ${ }^{26}$ Muslims, ${ }^{27}$ African-Ameri-

13. Bowers v. Hardwick, 478 U.S. 186 (1986) (upholding Georgia's anti-sodomy statute).

14. Will they ask us, for example, how we sat by while the Supreme Court limited affirmative action, or, conversely, ask how we could have tolerated a program that amounted to discrimination against whites? Will the children of present-day Catholics wonder how their parents could have resisted same-sex marriages? See, e.g., STEVEN W. Bender, Mea Culpa: Lessons on Law and Regret from U.S. History 12 (2015) (noting Bender's view that religion is not an infallible guide to predicting regret).

15. See, e.g., Doris Kearns Goodwin, Lyndon Johnson and the American DrEam (St. Martin's Press 1991) (1976) (depicting Johnson and his era in a favorable light); Randall Kennedy, Race Relations Law and the Tradition of Celebration: The Case of Professor Schmidt, 86 Colum. L. Rev. 1622 (1986) (noting the triumphalist quality of much constitutional law scholarship).

16. Presentism is "an attitude toward the past dominated by present-day attitudes or experiences"; presentism may manifest itself in judging past actors harshly for behavior that was not considered wrong at the time. Presentism, Merriam-Webster, http://www.merriam-webster.com/dictionary/presentism [https://perma.cc/MTV8NYNX].

17. Bender, supra note 14; see also, e.g., Peter Irons, Justice at War (Univ. of Cal. Press 1993) (1983) (noting that the case for Japanese internment was almost entirely fabricated).

18. Enslaving African-Americans or denying female suffrage, for instance.

19. BENDER, supra note 14 , at 23-28.

20. See id. at 4-8, 168-71.

21. Id. at $17-25$.

22. Id. at $35-58$.

23. Id. at $59-75$.

24. Id at 76-92.

25. Id. at $93-100$.

26. Id. at 101-12.

27. Id. at 113-25. 
cans ${ }^{28}$ and women, ${ }^{29}$ ending with a simple piece of advice: Stop dehumanizing these people today or risk condemnation tomorrow. ${ }^{30}$

In short, Bender's book catalogs a series of mistakes, past and present, that would make all but the most hardened cultural chauvinist wince. Some of these errors-especially those he discusses in the first twenty-five pages such as slavery, slave trafficking, Ku Klux Klan violence, the Tuskegee Syphilis Study, Chinese exclusion, Japanese internment, and the dispossession of Native Americans from their lands-are ones in which the legal system played a part. ${ }^{31}$ On the other hand, others were committed by society at large with little assistance from the judiciary. ${ }^{32}$

His division of effort-a few pages devoted to past errors and 125 to current problems - is understandable, even bracing. Anyone writing about atrocities might well glide over the former in an effort to get on with addressing current practices since these are, after all, the ones we are in a position to do something about. But the past can tell us a great deal-including that dehumanization is a less reliable guide than Bender believes. We dehumanize only some of the groups we abuse and recognize the humanity of others that we continue mistreating. By the same token, faith in law and legal institutions as bulwarks against mass mistreatment is probably misplaced-law often proves even slower to spot and ward off atrocity than society at large.

Though Bender's catalogue of missteps, past and present, is sobering-even brave ${ }^{33}$ - the solution may not be careful reflection as he posits. ${ }^{34} \mathrm{We}$ are unlikely to treat others better merely by pondering shameful episodes from the past. The distinguishing features of a new group-Muslims being a current example-are the very features that make it possible to separate them from existing groups that we now deem entitled to full respect. ${ }^{35}$ This risk is especially high if we have little to gain from modifying our behavior towards the new group. ${ }^{36}$

28. Id. at $126-48$.

29. Id. at 149-59.

30. See BENDER, supra note 14.

31. See, e.g., id. at 22 (noting Supreme Court approval of the internment of Japanese-Americans during World War II).

32. See, e.g., id. at 24 (quoting Thomas Jefferson and Thomas Reade Rootes Cobb on black inferiority).

33. Brave, because he defies convention: No one loves a nag, a scold, a Cassandra, or a worrywart.

34. See BENDER, supra note 14.

35. See Richard Delgado, Four Reservations on Civil Rights Reasoning by Analogy: The Case of Latinos and Other Nonblack Groups, 112 Colum. L. Rev. 1883 (2012) (discussing the pitfalls of this purely retrospective form of reasoning).

36. See Derrick A. Bell, Jr., Comment, Brown v. Board of Education and the Interest-Convergence Dilemma, 93 HARv. L. REv. 518, 522-26 (1980) (demonstrating how this breakthrough decision depended on a temporary alignment of black and white interests). 
And the risk turns out to be just as high for the legal profession, which is often as slow to recognize error as actors in other walks of life. ${ }^{37}$

This Review unfolds in two additional Parts. Part II shows the limitations of dehumanization as a touchstone for cruel practices. Finally, Part III offers a brief conclusion. The Review shows how one of the bulwarks Bender describes against mass atrocity-the judicial system-is much less effective than we like to think. ${ }^{38}$ Building on the authors' work on narrative theory, the Review shows how an "empathic fallacy" limits discourse and reflection-including the legal kind-on current practices, ${ }^{39}$ and how exposure to outsider stories can help, but only very slowly. ${ }^{40}$ Many breakthroughs, such as Brown $v$. Board of Education, ${ }^{41}$ arrive not as a product of inspired advocacy, but rather as a product of a new alignment of class interests. ${ }^{42}$ Groups such as gays and lesbians make few gains by merely pointing out their common humanity with the rest of us. Instead, experience shows that breakthroughs arrive when we come to see members of a group as familiar and valuable persons, and not the reverse. ${ }^{43}$ This is even truer with nonhuman interests, such as the environment or nonhuman animals. Here, empathy, except of an abstract nature, is slow in arriving. With animals, empathy sets in only after it dawns on us that they are,

37. With the law and judges, the stakes are often even higher than they are with ordinary citizens because judicial errors are apt to embed themselves in case law and legal culture, and resist change. See infra Section II.B; BENDER, supra note 14, at 4 (noting that Justice William Douglas regretted his decision in the Japanese-internment cases and that Justice Lewis Powell did the same regarding his role in Bowers $v$. Hardwick); see also Amy Chozick, Kenneth Starr, Who Tried to Bury Bill Clinton, Now Only Praises Him, N.Y. Times (May 24, 2016), http://www.nytimes.com/2016/05/ 25/us/politics/ken-starr-impeachment-bill-clinton.html (reporting Kenneth Starr's regret over his investigation of Bill Clinton's sexual indiscretions).

38. See BENDER, supra note 14, at 14-15 (discussing the hope that international human rights law may guard against flagrant misbehavior); infra Part II (discussing why this hope may be misplaced).

39. See Richard Delgado \& Jean Stefancic, Images of the Outsider in American Law and Culture: Can Free Expression Remedy Systemic Social Ills?, 77 CoRnell L. REv. 1258, 1261, 1281 (1992) (defining "empathic fallacy" and explaining its operation); infra Section II.B.4.

40. See Richard Delgado \& Jean Stefancic, Norms and Narratives: Can Judges Avoid Serious Moral Error?, 69 Tex. L. REv. 1929, 1955-58 (1991) (evaluating the case for exposure to diverse literature as means of quickening social conscience); infra Section II.B.4.

41. Brown v. Bd. of Educ., 347 U.S. 483 (1954).

42. See, e.g., Bell, supra note 36 (noting that the breakthrough decision arrived as a consequence of a rare alignment of class interests).

43. See, e.g., id.; Nathaniel Frank, Unfriendly Fire: How the Gay Ban UnDermines the Military and Weakens America 215-20 (2009) (noting that the lack of Arabic translators and interpreters-excluded from the military and intelligence branches because many of them were gay-interfered with national security before the ban was lifted). 
like us, conscious beings with interests of their own, rather than as a product of abstract reasoning or reflection. ${ }^{44}$

With fellow humans, the only measure that seems to reliably increase concern is getting to know them on a regular basis and forming relationships with them. ${ }^{45}$ Yet this can happen only once we have overcome housing and early school segregation-the very advances that racial antipathy blocks. And for lawyers and judges, formalism and stare decisis ensure that a new viewpoint is often even slower to arrive than it is for ordinary citizens. ${ }^{46}$

All societies exhibit some fear of outsiders; it may be an innate human response. Showing how it operates in an advanced JudeoChristian society like ours is a considerable achievement. But diagnosing the source of these failures could have been an even greater breakthrough that awaits, perhaps, Bender's next book. Such a project would focus more closely on the origins of past transgressions than does Mea Culpa's broad maxim: Avoid dehumanization.

Let us first consider dehumanization's role in explaining the mistreatment of our fellow humans, and then law's role in its relief.

\section{Why We Go Astray}

\section{A. Dehumanization}

Bender is more successful at showing the history and extent of atrocity than explaining it. He believes the major contributing factor is dehumanization, and although it does appear as a common thread in many of the situations he discusses, this is an artifact of selecting just some chapters in human history and not others. The Serbs and Bosnian Muslims do not dehumanize each other, but nevertheless slaughter members of the other tribe when the opportunity presents itself because they bear grudges dating back 500 years to specific incidents

44. First we perceive that animals have interests and struggle to survive. Then we develop empathy followed by a sense of kinship, and finally we decide to protect them from harm. See generally Chris Hegedus \& D.A. Pennebaker, Opinion, 'Animals Are Persons Too', N.Y. Times (Apr. 23, 2014), http://www.nytimes.com/2014/04/23/opinion/animals-are-persons-too.html (discussing one lawyer's efforts to secure personhood rights for animals); Nicholas Kristof, Opinion, A Humane Revolution, N.Y. TiMES (May 15, 2016), http://www.nytimes.com/2016/05/15/opinion/sunday/a-humanerevolution.html (discussing consumer-driven progress on animal welfare and noting that Ringling Bros. retired its elephants, "sending them off to a life of leisure in Florida," and that SeaWorld is doing much the same with marine mammals).

45. This is the famous social-contact theory. See Gordon W. Allport, The NAture of Prejudice 281 (Basic Books 25th anniv. ed. 1979) (1954); Richard Delgado \& Jean Stefancic, Hate Speech in Cyberspace, 49 Wake Forest L. Rev. 319, 334 (2014).

46. For an explanation of how this happens, see infra Section II.B. 
that make little sense to Western eyes. ${ }^{47}$ While each believes the other group is fully human, they simply despise each other.

In the case of Jews, their detractors (anti-Semites) do not hate them or see them as lowly, stupid, dirty, or lazy. Instead, they admire their supposedly high level of comfort and prosperity, but believe they attained it illegitimately-through sharp practice, usury, currency manipulation, and pushing themselves ahead. ${ }^{48}$ In short, they are not subhumans but superhumans, yet are still seen as despicable. ${ }^{49}$ Some are beginning to see Asian-Americans in the same light-colorless drudges who earn high grades through endless hours of studying while neglecting athletic and social skills and well-balanced personalities, combined with cheating, exam prepping carried to an excess, and grade grubbing. ${ }^{50}$ Jonathan Swift's parable of Gulliver's Travels shows how easy it is for a society to condemn a superior group, deem its gains ill gotten, and conspire to bring it down..$^{51}$

With other groups, second-class treatment takes the form of condescension. A certain type of male will treat women with exaggerated respect so long as he is able to relegate them to the realm of homemaking, child-rearing, and catering to their men. In societies organized along these lines, women end up cared for but limited in the respects in which they are permitted to develop their talents. They are not dehumanized exactly, but are placed on a pedestal on which one must stand and balance oneself carefully to avoid falling. ${ }^{52}$

47. See, e.g., Roger Cohen, Cross vs. Crescent: The Battle Lines Are Being Redrawn in Bosnia Along Old Religious Scars, N.Y. Tımes (Sept. 17, 1992), http:// www.nytimes.com/1992/09/17/world/cross-vs-crescent-battle-lines-are-being-redrawnbosnia-along-old-religious.html (discussing ancient enmities and their role in current aggression).

48. See Götz Aly, Why the Germans? Why the Jews?: Envy, Race Hatred, AND the Prehistory of THE Holocaust (Jefferson Chase trans., 1st U.S. ed. 2014) (2011) (discussing the cultural roots of antisemitism).

49. See Michael Morris, Standard White: Dismantling White Normativity, 104 Calif. L. Rev. 949, 951 (2016) (book review) ("If white racial identity hinges on white normativity instead of white superiority, then the racial minorities who outperform whites are not white; they are freaks and outliers.").

50. See Robert S. Chang, Toward an Asian American Legal Scholarship: Critical Race Theory, Post-Structuralism, and Narrative Space, 81 CALIF. L. REv. 1241, 1258-65 (1993) (criticizing the "model minority" myth, according to which Asians are privileged); Andrew Lam, In Asia, Cheating to the Test, Huffington Post: The Blog (Aug. 19, 2014, 4:33 PM) http://www.huffingtonpost.com/andrew-lam/in-asiacheating-to-the-t_b_5692497.html [https://perma.cc/F5T5-8F3D]; Nicholas Kristof, Opinion, The Asian Advantage, N.Y. Times (Oct. 10, 2015), http://www.nytimes.com/ 2015/10/11/opinion/sunday/the-asian-advantage.html.

51. See Jonathan Swift, Gulliver's Travels 21-48 (Robert DeMaria, Jr. ed., Penguin Books 2003) (1726) (describing the traveler's encounter with the Lilliputians).

52. See Jane Turner Censer, The Reconstruction of White Southern Womanhood, 1865-1895 (2003) (discussing women's struggle to break free from confining roles and achieve a degree of independence); MARGaRet Mitchell, Gone WITH THE WIND 62 (Simon \& Schuster 75th anniv. ed. 2011) (1936) (discussing exaggerated courtesy to women in the nineteenth-century American South). See generally Carol Gilligan, 
Finally, modern social science teaches that dehumanization is not necessary to get people to act reprehensibly toward each other. Stanley Milgram's experiments show that many of us will perform actions we believe will inflict great pain if ordered to do so by an authority figure. ${ }^{53}$ Germany's experience under the Third Reich shows that this holds true for nations where soldiers, prison guards, and even ordinary citizens carried out acts of great cruelty toward Jews, homosexuals, and the disabled, even though they did not especially hate them, at least not initially. ${ }^{54}$ Studies creating mock prison camps and separate blue-eyed and brown-eyed classroom groups show that we are much less able to resist peer pressure than we like to think. ${ }^{55}$ Dehumanization may facilitate this behavior, but experience teaches that it is not at all necessary.

\section{B. Law as Safeguard}

At any rate, if dehumanization lies at the heart of some mistreatment of fellow humans, can law help guard against its spread?

Apparently much less so than we might think. Mea Culpa shows that lawyers and judges are little better-and often worse-than the average grocer, social worker, pastor, or newspaper columnist at guarding against mistreatment of vulnerable subjects. ${ }^{56}$ The skeptical or defensive reader is invited to consider how the legal system has either stood by in the face of or played an active role in legitimating

In a Different Voice: Psychological Theory and Women's Development (1993) (noting that girls' psychological and moral development is not slower than that of boys, as other developmental psychologists had posited; instead, girls often exhibit a heightened sense of connection with others, which can easily be taken for moral equivocation and lack of decisiveness). "Falling" from the abovementioned pedestal, of course, often meant disgrace and ruin.

53. E.g., Stanley Milgram, Obedience to Authority (Perennial 1st Perennial Classics ed. 2004) (1974).

54. See, e.g., Hannah Arendt, Eichmann in Jerusalem: A Report on the BANALITY OF EVIL (Penguin Books 2006) (1963) (noting an apparent lack of animosity toward the Jews in Eichmann-the architect of their deportation to concentration camps); Robert Jay Lifton, The Nazi Doctors (2000 ed. 2000) (noting that Nazi doctors may have come to develop hatred or contempt for their subjects as a defense mechanism). See generally Charles Lane, Opinion, Shining a Light on One of the High Court's Darkest Moments, WASH. POST (Feb. 17, 2016), https://www.washingtonpost. com/opinions/shining-a-light-on-one-of-the-high-courts-darkest-moments/2016/02/17/ e4cc24f6-d4d1-11e5-9823-02b905009f99_story.html [https://perma.cc/J7RN-L5HX] (suggesting that the early twentieth-century fad of "racial hygiene" was the result of "groupthink" rather than hatred).

55. See Philip Zimbardo, The Lucifer Effect: Understanding How Good People Turn Evil (2007) (discussing the Stanford prison experiment); William PeTERS, A Class Divided (Yale Univ. Press 1987) (1971) (discussing the 1970 "browneyed" vs. "blue-eyed" classroom experiment).

56. See, e.g., BENDER, supra note 14. 
torture, ${ }^{57}$ solitary confinement, ${ }^{58}$ undeclared wars,${ }^{59}$ sexual trafficking, ${ }^{60}$ capital punishment for juveniles and the insane, ${ }^{61}$ and racebased immigration crackdowns ${ }^{62}$-all in very recent times, even when journalists, the public, and other nations were clamoring for an end to these practices. Consider four interrelated reasons why courts and other legal actors often seem to go through life with clear consciences, even if it becomes plain years later that they perpetrated something inexcusable for which they feel perfectly terrible and apologetic.

\section{In Law, Reversal Is Rare and Structurally Isolated}

One reason is that law by its nature is slow to reverse itself. Individual people, legislatures, and town councils admit serious error and apologize for it from time to time, but examples of judges and other legal actors who do are very few. If true love means never having to say you are sorry, ${ }^{63}$ being a lawyer or judge seems to mean much the same.

Appellate courts reverse lower courts when they believe they have applied a statute or constitutional provision incorrectly. ${ }^{64}$ And trial

57. See Bender, supra note 14 , at 119-23; see also David Cole, Torture Memos: Rationalizing the Unthinkable (2009) (discussing the role of government lawyers in justifying waterboarding and other forms of torture).

58. See Bender, supra note 14, at 124-25; see also Barack Obama, Opinion, Why We Must Rethink Solitary Confinement, WAsH. Post (Jan. 25, 2016), https:// www.washingtonpost.com/opinions/barack-obama-why-we-must-rethink-solitary-con finement/2016/01/25/29a361f2-c384-11e5-8965-0607e0e265ce_story.html [https:// perma.cc/2Q9C-NPZD] (announcing a ban on federal solitary confinement of juveniles and those convicted of "low-level infractions" and urging states to follow suit).

59. Iraq, for instance. See BENDER, supra note 14, at 119; see also Richard Delgado \& Juan F. Perea, Racial Templates, 112 Mich. L. Rev. 1133, 1151 (2014) (discussing an ill-considered war).

60. See BEnder, supra note 14, at 14-16, 48; see also Nicholas Kristof, Opinion, Meet a 21st-Century Slave, N.Y. Times (Oct. 24, 2015), http://www.nytimes.com/2015/ 10/25/opinion/sunday/meet-a-21st-century-slave.html ("A crucial step, whether in Nepal or the United States, is ending the impunity for pimps and traffickers . . . . In America as well, we need to prosecute traffickers rather than their victims.").

61. See BENDER, supra note 14, at 104; see also Roper v. Simmons, 543 U.S. 551, 562-64, 568 (2005) (discussing society's evolving standards of decency with respect to the execution of the mentally retarded and invalidating, for the first time, the death penalty for children under eighteen).

62. See Bender, supra note 14, at 43-58; see also Richard Delgado \& Jean Stefancic, Southern Dreams and a New Theory of First Amendment Legal Realism, 65 EMORY L.J. 303, 314-19 (2015) (discussing recent anti-immigrant legislation in the South); The Editorial Board, Editorial, Migrant Children Deserve a Voice in Court, N.Y. Times (Mar. 8, 2016), http://www.nytimes.com/2016/03/08/opinion/migrant-chil dren-deserve-a-voice-in-court.html (offering a judge's idea that toddlers can represent themselves in immigration court as an example of views towards immigration and advocating that counsel be provided for these children).

63. Erich Segal, Love Story (1970).

64. E.g., Nat'l Fed'n of Indep. Bus. v. Sebelius, 132 S. Ct. 2566 (2012) (discussing whether a key provision in the Affordable Care Act is a "tax," and reversing in part the Eleventh Circuit). 
courts sometimes vacate a judgment and retry a case when it appears a key fact was missing or suppressed. ${ }^{65}$ But a higher court almost never overturns its own previous precedent merely because it was repulsive or wrong. And when this occurs, as Derrick Bell noted, an external reason often plays a part. ${ }^{66}$

With reparations for black slavery, lynching, and Jim Crow laws, a number of governmental entities have taken steps toward admitting error. ${ }^{67}$ But lawsuits for monetary damages have failed on causation grounds. ${ }^{68}$ Courts reason that few direct victims of past mistreatment are still alive and few living Americans had a hand in their sufferinglegalistic arguments that ignore the growing conviction that American society committed a great wrong that it should now redress. ${ }^{69}$

And regarding Japanese internment, a federal trial court expunged the conviction of Fred Korematsu while stressing that the Supreme Court decision upholding the broad program of which it was a part stood. ${ }^{70}$ Why such reluctance to admit error? If all the engineers in a society came to the realization that a certain style of bridge building resulted in frequent collapses, engineers would quickly get out their slide rules and start working on a better design. But in law, this seems not to happen, at least not so readily. Could legalisms such as stare decisis and the straight-line causation requirement be making lawyers, who like to think of themselves as quick-witted and highly analytical, in fact obtuse? ? $^{71}$

65. E.g., Korematsu v. United States, 584 F. Supp. 1406 (N.D. Cal. 1984) (granting a writ of coram nobis and vacating the petitioner's wartime detention as based on falsified evidence).

66. See Bell, supra note 36 (using Brown v. Board of Education as an illustration, Bell explains that, like many such breakthroughs, it arrived as a result of a rare alignment of black and white interests rather than a deeply felt conviction that segregation was wrong).

67. See Bender, supra note 14, at 17-19. As an additional example, Florida and the town of Rosewood apologized in 1994 for a race riot that leveled the black part of town and took many lives, though this involved "compensation" rather than "reparations." Roy L. Brooks, When Sorry Isn't Enough: The Controversy over Apologies and Reparations for Human Injustice 436 (1999).

68. E.g., In re African-Am. Slave Descendants Litig., 471 F.3d 754, 759 (7th Cir. 2006) ("[The] causal chain is too long and has too many weak links for a court to be able to find that the defendants' [companies that profited from slavery] conduct harmed the plaintiffs [descendants of slaves] at all."). See generally Charles J. Ogletree, Jr., Opinion, Litigating the Legacy of Slavery, N.Y. TIMEs (Mar. 31, 2002), http:// www.nytimes.com/2002/03/31/opinion/litigating-the-legacy-of-slavery.html (noting that, unlike slavery-based reparations claims, previously successful reparations claims involved living, identifiable plaintiffs).

69. See, e.g., African-Am. Slave Descendants Litig., 471 F.3d at 759; Randall Robinson, The Debt: What America Owes to Blacks (Plume 2001) (2000) (discussing arguments for and against reparations for slavery and Jim Crow).

70. Korematsu, 584 F. Supp. at 1420.

71. See, e.g., DeShaney v. Winnebago Cty. Dep't of Soc. Servs., 489 U.S. 189, 212-13 (1989) (Blackmun, J., dissenting) (lamenting that young Joshua DeShaney did not enjoy a constitutional right to state protection from child abuse and the majority's justification that it was "compelled by existing legal doctrine"). 
Indeed, one would be hard put to identify a non-legal profession that constantly stumbles so badly and then feels terrible half a century later. Musicians, for example, are rarely consumed with deep regret, and the same is true for most novelists, engineers, pastors, and scientists. All make errors, of course, from time to time-they compose bad symphonies and novels that digress and lose their way. Sometimes new engineering marvels turn out to be anything but, or to have unintended consequences such as pollution, automobile crashes, or increased congestion. But-unlike lawyers-when they do make errors, members of these other professions correct their mistakes and simply move on, composing a better symphony, reinterpreting scripture, abandoning failed theories, or building a better bridge.

\section{An Adversary System Based on Argumentative Skill}

Another reason may be the adversary system itself, which rewards skillful argument based on rhetoric, bluffing, and exaggeration. ${ }^{72}$ Law is one of the most word-bound professions-it rewards verbal facility and clever turns of phrase. Words may, of course, be used to convey knowledge and arrive at the truth. But they may also be used to mislead or even lie. A profession that thrives by stringing together words may easily find itself thinking, unconsciously, that this is sufficient unto itself. History can be unkind to one who acts in this fashion, particularly if he or she is not too scrupulous in whom he or she chooses as a client.

\section{Stare Decisis ("My Hands Are Tied")}

If lying and exaggeration are traps for the lawyer who sets out in life to do only good, stare decisis and legal formalism are the corresponding traps for a conscientious judge. A magistrate who deviates too far from settled precedent-including from a former era in which Indians were savages, women second-class citizens, and black schoolchildren separated from their white counterparts-risks criticism or reversal for judicial activism. Detractors are apt to remind the magistrate that

72. The idea is that two clever advocates, each developing opposite propositions, will in some unexplained manner help a trier of fact arrive at the truth through crossexamination. See United States v. Salerno, 505 U.S. 317, 327-30 (1992) (Stevens, J., dissenting); 3 John Henry Wigmore, A Treatise on the Anglo-American System of Evidence in Trials at Common Law § 1367, at 27 (2d ed. 1923) (1904) (deeming cross-examination "the greatest legal engine ever invented for the discovery of truth," but also stating that "[a] lawyer can do anything with" it and that it can be used to "make the truth appear like falsehood"). For more regarding bluffing and wheedling as lawyers' tools, see Pierre Schlag, This Could Be Your Culture - Junk Speech in a Time of Decadence, 109 HaRv. L. Rev. 1801, 1816-17 (1996) (book review); Richard Delgado, Recent Writing on Law and Happiness, 97 Iowa L. REv. 913, 929 (2012) (book review). 
his or her job is to apply the law, not make it, and that if the law is unjust or unfair, it is the legislature's job to fix it. ${ }^{73}$

\section{Clarence Darrow's Predicament: Brilliant Retorts and the Empathic Fallacy}

A prime hope of many reform-minded lawyers, including perhaps many readers of this Review, is that a new legal story or narrative (such as "Poor Joshua") that reveals cruelty, self-interest, or stupidity in a current practice will spark reflection and ultimately better law. ${ }^{74}$

But recent scholarship shows that progress through inspired storytelling is at best slow and halting. ${ }^{75}$ A new story will confront a host of others that a reader has heard from numerous sources in the surrounding society and internalized. If these stock narratives, which essentially establish the reader's consciousness, deem the new one ridiculous, extreme, or wrong, the reformist storyteller (who may be a lawyer) will face a difficult hurdle-in an important sense, "we are our [own] stock of narratives, and they us." 76

Moreover, we have little option but to judge a new narrative or argument in terms of the ones we have internalized to that point. If, starting in law school, master narratives such as "without intent, no racism"; "no liability without direct causation"; and "no one can bring

73. Regarding the straitjacket of legal formalism, particularly the First Amendment kind, see Delgado \& Stefancic, supra note 62. See generally, e.g., Michael Cieply, Film Academy Trips over Its Own Rules, Racing to Answer Calls for Diversity, N.Y. Times (Feb. 22, 2016), http://www.nytimes.com/2016/02/23/business/media/film-acad emy-trips-over-its-own-rules-racing-to-answer-calls-for-diversity.html (noting that many Academy of Motion Picture Arts and Sciences governing board members wished to diversify the board but found themselves blocked by the Academy's rules). By the same token, lawyers may be quick-witted and highly analytical yet still bound by structural constraints that only extensive collective political action could overcome.

74. See, e.g., DeShaney, 489 U.S. at 212-13 (Blackmun, J., dissenting).

75. Delgado \& Stefancic, supra note 39 (describing the limits of exhortation and oratory). But see Richard Delgado, Storytelling for Oppositionists and Others: A Plea for Narrative, 87 Mich. L. REv. 2411 (1989) (encouraging the use of carefully framed stories and counter-narratives); Kathryn Abrams, Hearing the Call of Stories, $79 \mathrm{CA}$ LIF. L. REv. 971 (1991) (advocating storytelling in the context of feminist legal scholarship).

76. Delgado \& Stefancic, supra note 39 , at 1277-84. This generalization ("we are our current stock of narratives"), $i d$. at 1280 , holds especially true for the law. Imagine, as a thought experiment, that one ran across a book professing to be a patent law treatise that opened by declaring, as a fundamental premise, that all inventions belonged to the world and ought to be immediately available to all for free. One's initial reaction is apt to be: "This isn't a patent law treatise, but something else, perhaps a fantasy." Similarly, a treatise on the law of property written in 1700 that declared that human beings could not belong to others as slaves would have struck most readers as absurd-as not-law. By contrast, an engineering book or article that began by proposing a new approach to bridge building-suggesting that bridges over 800 feet long were too expensive and dangerous in high winds and that society should consider investing in underwater tunnels instead-would be unlikely to meet such cavalier rejection ("that's not engineering"). Readers would instead consider the substance of the author's suggestion and arrive at their own conclusion. 
a suit without demonstrating harm to himself" are drilled into us, we are very unlikely to escape these ways of organizing reality. They will seem like the only way of doing so-like the unabashed and unquestionable truth. For example, Justice Antonin Scalia's proposition, shortly before his death, that African-American students might be better off attending low-ranked schools where the competition is less keen than it is in more elite ones ${ }^{77}$ may have struck many in the liberal community as outrageous and a modern-day revival of separate but equal. But he had likely heard it many times in conservative circles. ${ }^{78}$ To members of his discourse community, it was and is a master narrative, an article of faith, and a reasonable means of organizing society-in short, a hard truth.

\section{Law's Limits and the Reconstructive Paradox}

The above considerations converge to explain why legal actors are often unable to correct or even recognize cases of systemic injustice, even when they are squarely in front of them. Like much of social discourse, the legal kind is best at identifying and correcting small, bounded errors, not broad systemic ones such as racism or Jim Crow. ${ }^{79}$ For reform to occur, many practices must change at once; otherwise, momentum slows and the tug of the familiar drags things back to where they were before. ${ }^{80}$ Agreed-upon rules of standing, precedent, and causation, however, assure that things can only change slowly, one piece at a time. Thus, legal means are poorly calculated to facilitate recognizing and correcting broad-scale injustices.

77. Dan Roberts, Justice Scalia: Minority Students May Be Better off Going to 'Lesser Schools', Guardian (Dec. 9, 2015, 2:11 PM), http://www.theguardian.com/ law/2015/dec/09/supreme-court-affirmative-action-fisher-v-university-of-texas [https:// perma.cc/8GN6-586F].

78. See, e.g., Richard H. Sander, A Systemic Analysis of Affirmative Action in American Law Schools, 57 STAN. L. REv. 367 (2004) (arguing that affirmative action harms minorities). Sander's article proved very popular with tough-love conservatives. See David Pluviose, U.S. Civil Rights Commission Condemns Affirmative Action in Law School Admissions, Diverse (Sept. 10, 2007), http://diverseeducation.com/arti cle/9253/ [https://perma.cc/6NZ2-3F43].

79. That is, a court proceeding is a good way to determine whether Jim overcharged Joe for a pound of beef. But it is not so readily able to determine whether beef is a vital component of the human diet, the slaughterhouse industry kills animals under humane conditions, or vegetarianism is a superior means for feeding a nation.

80. We have called this the "reconstructive paradox." See Richard Delgado \& Jean Stefancic, The Social Construction of Brown v. Board of Education: Law Reform and The Reconstructive Paradox, 36 WM. \& MARY L. Rev. 547, 555 (1995). ("Because Brown was interpreted against the background of . . understandings, traditions, and expectations [having to do with segregation] ... the case had relatively little impact. ... The gain [school integration] was quickly swallowed up by interpretive effects emanating from [other areas].") 


\section{CONClusion}

Mea Culpa shows that we find it easiest to do the right thing when it advances our own interest. When we fall short of our highest ideals, it is often because we dehumanize the object of our mistreatment. Reflection, exhortation, and even legal principle often prove unreliable guides to considerate action. If we are to avoid bringing shame and harsh judgment on ourselves - and doing harm to the environment, animals, and our fellow humans-we must develop closer bonds of knowledge and familiarity with them. Our checkered history, drawn by Steven Bender, shows that law and religion are less reliable preceptors than simple knowledge and closeness to those who, after all, are our kin and companions on the planet. 